\title{
Review Paper on: Potential and Constraints of Teff Row Planting for Enhancing Productivity
}

\author{
TEKLE LOMBAMO* 1 \\ 1.Wolaita Sodo University College of Agriculture, Department of Plant Science P.O. Box 01 \\ 2.School of Plant and Horticultural Science, College of Agriculture, Hawassa University, P. O. Box 05, Hawassa \\ Ethiopia
}

\begin{abstract}
Agriculture is the basis of Ethiopian economy, accounting for $46 \%$ of its GDP and $90 \%$ of its export earning and employing $85 \%$ of the countries labor force. Increasing agricultural productivity is absolutely necessary to feed the increasing population by increasing land productivity.Teff is Ethiopia's most important staple crop. Teff has the largest value in terms of both production and consumption in Ethiopia and the value of the commercial surplus of teff is second only to coffee. However, despite its importance in Ethiopia, teff yields are low.Technologies for increasing teff grain and straw yields such as row planting, transplanting, reduced seed rates, improved seed adoption and improved fertilizer application, are being explored by the ATA and MoA, but to date are still not widely adopted.Even though ATA research tends to find large positive effects to row planting alternative agronomic research findings cast some doubts on the claim that row planting is able to achieve enormous yield increases.
\end{abstract}

Keywords: Constraints of row planting, Row planting, Teff, Transplanting

DOI: $10.7176 / \mathrm{JBAH} / 10-3-06$

Publication date: February $29^{\text {th }} 2020$

\section{INTRODUCTION}

Agriculture is the basis of Ethiopian economy, accounting for $46 \%$ of its GDP and $90 \%$ of its export earning and employing $85 \%$ of the countries labor force (Mulatu, 1999; UNDP, 2002). Increasing agricultural productivity is absolutely necessary to feed the increasing population by increasing land productivity.

Teff is Ethiopia's most important staple crop. Teff has the largest value in terms of both production and consumption in Ethiopia and the value of the commercial surplus of teff is second only to coffee (Minten etal. 2013). However, despite its importance in Ethiopia, teff yields are low. In the production year 2012-2013, yields were 1.4 metric tons $(\mathrm{mt} / \mathrm{ha})$, significantly lower than other cereals, such as maize $(3.1 \mathrm{mt} / \mathrm{ha})$, sorghum and wheat (both $2.1 \mathrm{mt} / \mathrm{ha}$ ) (CSA 2013). This low teff yield is seemingly explained by the limited knowledge about possible avenues for improving teff productivity, combined with problems inherent to teff botany. Teff research has received limited national and international attention, the latter presumably because of its localized importance in Ethiopia (Berhane etal. 2011, Fufa etal. 2011). Moreover, teff yields are low because of agronomic constraints that include lodging, low modern input use, and high post-harvest losses (Habtegebrial etal. 2007, Berhe etal. 2011, Fufa etal. 2011). The national average yield for teff is currently below 1 ton per hectare (Tareke, 2008). Since teff is the staple food of most Ethiopian people, the present production system cannot satisfy the consumers' demand (Tareke, 2008). This is because the farming system that farmers use is backward which is not supported by modern technologies. This means the local people use broadcasting system rather than using row sowing. Reducing the high seed rate i.e. $25 \mathrm{~kg} /$ ha that the farmers use to low seed rate i.e. $5 \mathrm{~kg} / \mathrm{ha}$ is obtained $500-1200 \mathrm{~kg} / \mathrm{ha}$ from broadcast and $3400-5100 \mathrm{~kg} / \mathrm{ha}$ from row planting (Tareke, etal. 2008). This shows that the new approach i.e. the row planting has a fourfold increase in yield, moreover it increases tiller number, producing strong tiller culms and it increases number and quality of seeds.

Ethiopia is a case in point. While Ethiopia has recently experienced one of the largest agricultural growth spurs in SSA (an average of six percent per year since 2000), maintaining this high growth rate will require successful adoption of new yield-increasing technologies (Dadi etal. 2004; Dorosh and Rashid, 2012). To gain more insight in how the adoption of improved technologies can possibly increase land productivity in these settings, we study the case of row planting of teff in Ethiopia. Teff is Ethiopia's most important staple crop (at least in terms of area planted and value), but national average yield levels are low. One of the presumed reasons is that current agronomic practices constrain teff productivity. Farmers typically broadcast teff seeds, i.e. scattering seeds by hand, at high seed rates. This impedes teff yields because the uneven distribution of the seeds makes weeding difficult and increased competition with weeds and other teff plants lowers nutrient uptake by the individual teff plant (Berhe etal. 2011; Fufa etal. 2011). Technologies such as row planting and transplanting, where the seed rate is reduced and more space between seedlings is given, are assumed to be superior to traditional broadcasting because they allow for weeding, diminish competition between teff seedlings, and allow for better branching out (tillering) of teff plants.

Recently it has been argued that the traditional sowing technology is a major constraint to increased teff 
productivity (Berhe etal. 2011). Farmers typically plant teff by broadcasting, scattering teff seed by hand at a high seed rate. Alterna-tive planting methods, such as row planting seeds or transplanting seedlings, in which the seed rate is reduced and more space between plants is given, are seen as being superior to traditional broadcasting (Berhe etal. 2011, Fufa etal. 2011). Experiments on these alternative planting methods in controlled settings have shown large and positive impacts on teff yields (Berhe etal, 2011, Fufa etal. 2011). As a consequence, in 2013 the Ethiopian government rolled out a nationwide campaign to promote the use of improved technologies for teff production, including row planting, aiming to scale up their adoption to almost 2.5 million teff farmers.

Technologies for increasing teff grain and straw yields such as row planting, transplanting, reduced seed rates, improved seed adoption and improved fertilizer application, are being explored by the ATA and MoA, but to date are still not widely adopted. In 2011, 1,400 farmers following the ATA and the MoA recommended technologies experienced an average yield increase of 75\%, with high performing farmers experiencing yields of 50 quintals/ha. Similar results were shown by 90 participating Farmer Training Centres (FTCs). These yield increases were proven to positively impact small holder farmers economically. Other technologies the ATA and MoA have explored are mechanized teff row planters, harvesters and threshers. The combinations of these technologies are expected to double and sometimes triple small holder productivity.

In 2012 the ATA, MoA, RBoAs, EIAR, Regional Agricultural Research Institutes (RARIs) and Public Seed Enterprises (PSEs) conducted a large scale demonstration of improved tef seed and agronomic practices, targeting over 167,000 farmers with improved agronomic practices and seed in Amhara, Oromia, SNNP and Tigray regions. The experiences gathered in this large scale demonstration are intended to shape the planned 2013-2015 scale ups to bring improved tef technologies to 2.5 million farmers.

However, the impacts of the widespread promotion campaign of row planting of teff, in particular, on land and labor productivity are unknown. This is mainly due to a lack of reliable and objective farm level data. Moreover, no systematic effort has yet been put into examining farmers' perceptions after they experimented with the new sowing techniques. The contribution of this paper is to analyze the impact of the promotion campaign of row planting of teff on land and labor productivity and infer farmers' perception about the new planting technique and the promotion thereof.

Objective: to measure potential and constraints of teff row planting for enhancing productivity.

\section{BACKGROUND}

\subsection{Origin, distribution, history and botany of teff}

Teff (Eragrostis tef [Zucc.] Trotter) is an allotetraploid $(2 n=4 x=40)$ cereal crop grown primarily in Ethiopia. Ethiopia is the center of origin and diversity of teff. It is entirely cultivated only in Ethiopia as food crop and the crop is found in most of the country especially so in the highlands at altitude ranging from 1800 to 2100 meters above sea level as it can be grown under diverse agro-ecological conditions. The main production areas are in Amhara and Oromia regions and, to a lesser extent, in Tigray and the Southern Nations, Nationalities and Peoples (SNNP) regions and also distributed to several other countries in the $19^{\text {th }}$ century, and it is now cultivated as a forage grass in Australia, India, Kenya and South Africa (Costanza etal., 1979). Teff is resistant to extreme water conditions, as it is able to grow under both drought and waterlogged conditions (Teklu and Tefera 2005; Minten etal., 2013). Combined with its low vulnerability to pest and diseases, it is considered a low risk crop (Fufa etal, 2011; Minten etal., 2013). Teff is sown during the main meher rains between July and November, while harvesting is done in February. Seeds are broadcasted on a well ploughed soil and lightly covered with soil until germination. During the growing period, several weedings are often required (Assefa etal., 2011).

Teff is the country's most important staple crop in terms of both production and consumption, at least in value terms. During the 2012/13 meher rains, more than 6 million farmers allocated 22 percent of the national grain area to teff. On these teff lands, a total output of almost 4 million metric tons was obtained, accounting for 16 percent of all grain output. In 2013, the average teff yield reached 1.4 tons per hectare an increase of eight percent from 2012 (CSA 2013). Intensive studies carried out on teff in USA universities initiated its cultivation for both grain and forage has also begun in USA.

Between 8,000 and 5,000 BC, the people of the Ethiopian highlands were among the first to domesticate plants and animals for food and teff was one of the earliest plants domesticated. Teff is believed to have originated in Ethiopia and Eritrea between 4,000 BCE and 1,000 BCE. Genetic evidence points to E. pilosa as the most likely wild ancestor. A 19th century identification of teff seeds from an ancient Egyptian site is now considered doubtful; the seeds in question (no longer available for study) are more likely of E. aegyptiaca, a common wild grass in Egypt.

Studies so far carried out on morphological, cytological and biochemical characters of wild and cultivated species of teff revealed that Ethiopia is the origin and center of diversity of teff even though the wild relative, Eragrostis pilosa, a weedy species, occurs throughout the world in tropical and temperate regions (e.g. Vavilov, 
1951). This wild relative is the closest relative of the cultivated teff, E. tef. E. pilosa is also an allotetraploid and has a karyotype similar to E. tef (Tavassoli, 1986). These two species are similar morphologically. The only known consistent morphological distinction between E. pilosa and E. tef is spikelet shattering of E. pilosa.

The multi-floreted spikelets of E. pilosa readily break apart at maturity as a means of natural seed dispersal, whereas the lemmas, paleas, and caryopses of $E$. tef remain attached to the rachis at maturity and thereby facilitate harvesting (Phillips, 1995). It is speculated that the transition from shattering to non-shattering is one of the most common traits altered during the domestication process as it allows farmers to control seed dispersal. The current teff breeding program makes interspecific crosses between E. pilosa and E. tef with fully fertile resultant progenies. Hence, it is highly likely that Ethiopian farmers domesticated teff from E. pilosa and altered key agronomic features such as seed mass and spikelet shattering through generations of selections. Furthermore, ( Endeshaw etal., 1995) reported as there is anthropological evidence that E. pilosa is harvested and used as a food source in much the same fashion as $E$. teff during times of food scarcity.

Teff is a C4, self-pollinated annual grass, $40-80 \mathrm{~cm}$ tall. It has a shallow fibrous root system with mostly erect stems, although some cultivars are bending or elbowing types (Plate 1). Its sheaths are smooth, glabrous, open and distinctly shorter than the internodes. It has a panicle type of inflorescence showing different forms from loose to compact, the latter appearing like a spike. The flowers of teff are hermaphroditic with both the stamens and pistils being found in the same floret (Hailu etal., 1990). Florets in each spikelet consist of three anthers, two stigmas and two lodicules that assist in flower opening. Its grain is tiny with $0.9-1.7 \mathrm{~mm}$ long and $0.7-1 \mathrm{~mm}$ wide and its color varies from white to dark brown (Tadesse, 1975).

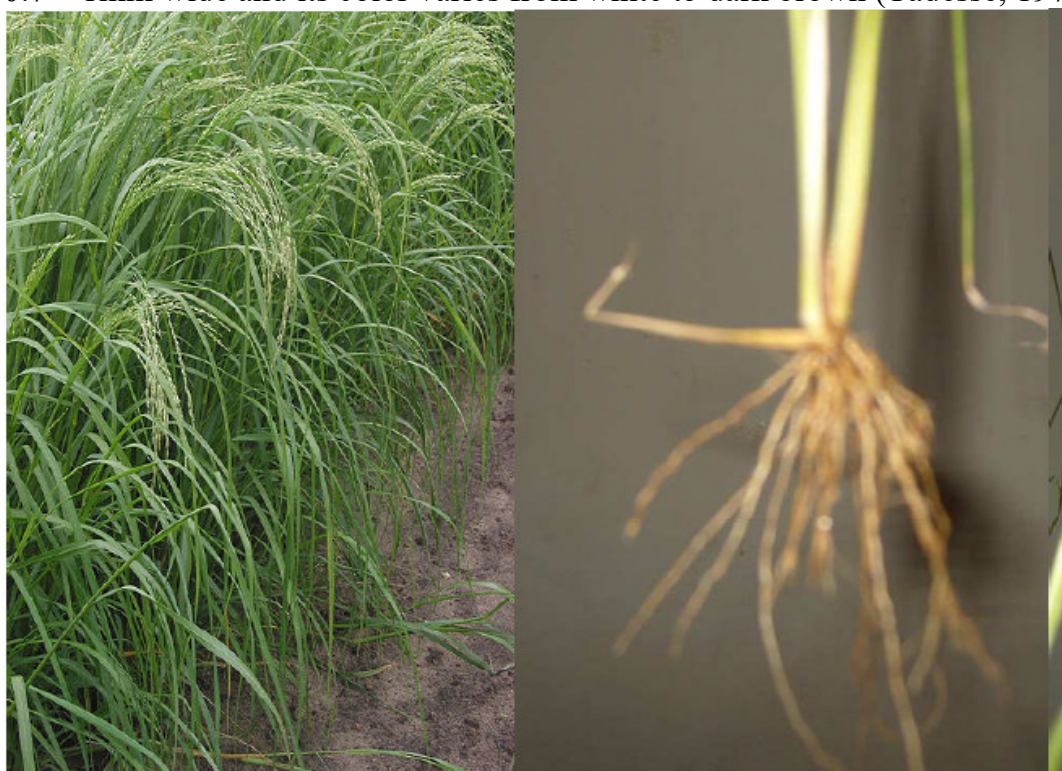

A)
B)

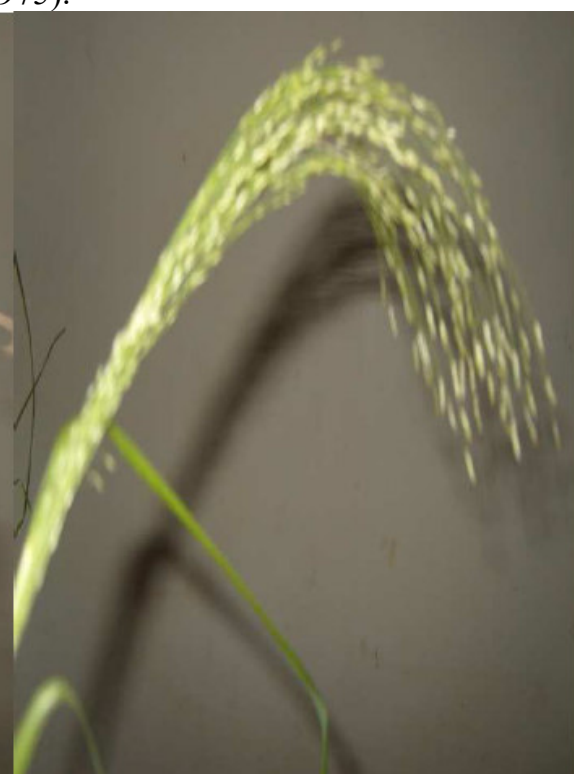

C)

Figure1. Morphological structure of teff crop: A) the whole plant; B) root and C) panicle

Plants with C4 pathway have a 'Kranz' type of leaf anatomy referring to the bundle sheath, a vascular tissue containing large and thick cell wall with prominent chloroplasts. Possessing such leaf structure helps $\mathrm{C} 4$ plants to increase the concentration of $\mathrm{CO}_{2}$ available to the Calvin cycle even under stress conditions by inhibiting photorespiration. Previous studies such as (Hirut etal., 1989) and (Etagegnehu, 1994) showed that teff possesses typical C4 leaf structure. It has two layers of bundle sheath and a single layer of mesophyll cell. Granal chloroplasts are present in both tissues with higher concentration in the bundle sheath cells.

\subsection{Agro-ecology and soil suitability for teff}

In Ethiopia, teff performs well in 'Weina dega' agro-ecological zones or medium altitude (1700-2400 m above sea level) (Habtamu, etal., 2007). An altitude ranging from sea level to 2800 masl with varying mean annual rainfall of $750-850 \mathrm{~mm}$ and the mean temperature between 10 and $27 \mathrm{c}^{0}$ are suitable for optimal agronomical environment for teff cultivation (Seyfu, 1997). Interestingly, teff can thrive well in both waterlogged as well as drought condition.

The first plowing for teff production in most part of the country is done as soon as the previous crop is harvested. In less weed prone areas, it is done after the onset of the small (belg) or main (kiremt) rainy seasons (Fufa etal., 2001). Teff needs high tillage frequencies as compared to other cereal crops in Ethiopia. Also, it requires firm, level seedbed, free from clods and stumps (Deckers etal., 2001). With respect to teff cultivation on Vertisols, several plowings are necessary, occasionally as much as 12 times, relative to Nitosols (Deckers etal., 2001). According to (Kenea etal., 2001), the tillage frequency for teff in Ethiopia ranges from 3 times in 
Nazareth to 12-times in western Wellega. Though research results indicated teff grain yield increased with increasing number of plowings (IAR, 1998). Others recommended tillage frequency for teff to be 3-5 times (Melesse, 2007), 5-9 times especially in high rainfall areas (Tarekegn etal., 1996) and 4-times (Nyssen etal., 2000). Generally, the tillage frequency is not consistent from region to region, from soil type to soil type and from farmer to farmer.

\subsection{Production activities in teff cultivation}

The calendar for teff production activities takes place both during short (Belg) and long rainy seasons, frequent ploughing of land is the first requisite in order to pulverise the soil for fine seedbed preparation congenial to germination of tiny teff seeds. Hand broadcast seeding is the traditional sowing method with seed rate varying from 25 to $50 \mathrm{~kg} / \mathrm{ha}$ (Tareke, 2008) depending upon germination ratio. The blanket fertilizer recommendation for teff is $100 \mathrm{~kg}$ each of DAP and Urea per hectare for moisture sufficient area made by the Ministry of agriculture. However, the actual dose of fertilizer application is below such blanket recommendation due to the expected drawback with lodging, moisture and weed problems. Two hand weeding are generally recommended. Teff is harvested when panicle gets grayish in order to avoid losses from shattering by cutting the lower part of the culm with sickle, laying the crop to dry for about seven days and finally threshed (Tareke, 2008).

Generally teff is mainly cultivated as a mono crop, but occasionally grows under a multiple cropping system (Seyfu, 1989). Diversification in agro climatic zonation does not allow allocation of a specific date of sowing (Tareke, etal). A delay in planting date from second week of July to first week of August reduces the tef yield by $30 \%$ (Teshome and Verheye, 1993).

\subsection{Uses and importance of teff}

It has also high nutritional value. When teff is compared to other cereals, it has more value than others cost wise as well as cultural values (Tareke, 2008). But it is the lowest in yield of all the cereals grown in the country. In Ethiopian culture for instance, the food served on weddings, New Year occasions or any celebrations, without injera which is traditional and staple food made of teff, is unthinkable (Tareke, 2008). Teff has also a lot of fanatic consumers, like the top Ethiopians sportsmen Haile Gebreslassie and Kenenisse Bekele (Turkensteen, 2008), they say that the teff products are not only gluten free but might help consumers to control their weight. Different then the modern grains teff helps the body to be fit for life. They think that products made out of teff, including enjera, helps them break international records over and over again. This is possible because teff has a high content of iron. This made that the hemoglobin in the blood is higher, so more oxygen can be transmitted, and the sportsmen can reach better sport results.

Moreover, some is used to prepare homemade beverages and sometimes for making porridge. The grain is used to made local alcohol drinks called Tela and Katikala (Seifu, 1993). The grains owing to its high mineral content ,has started to be used in mixture with soyabean ,check pea and other grains in the baby food industry (Seifu ,1997). Teff has as much or even more food value than the major grains; wheat, barley, and maize. This is probably because it is always eaten in the whole grain form. The germ and bran are consumed along with the endosperm. According NRC (1996), teff is reach in energy $(353-367 \mathrm{~K} \mathrm{cal} / 100 \mathrm{~g})$. Its fat content averages about $2.6 \%$. The protein content is as good as or better than that of other cereals and it ranges from $8 \%$ to $15 \%$ average $11 \%$. The protein digestibility is probably high because the main protein fraction, albumine, glutline, and globulin are the most digestible types. The vitamin content seems to be about average for a cereal. The level of minerals is also good; (average ahs content is $3 \%$ ). Teff is reported rich in iron calcium, potassium, and phosphorus. The iron and calcium contents $(0.011-0.033 \%)$ and (0.1-0.15) respectively are especially notable (NRC, 1996).

Teff is predominantly grown in Ethiopia as a cereal crop and not as forage crop. However, when grown as a cereal, farmers highly value the straw of teff and it is stored and used a very important source of animal feed especially during the dry season. Ethiopian farmers relay on it to strength their oxen at the end of winter; a time when fresh grass is unavailable but the planting season is coming. Farmers feed teff straw preferentially to lactating cows and working oxen. Cattle prefer teff straw to the straw of any other cereal and its price is higher than that of other cereals (Seifu, 1997). It is both nutritious and extremely palatable to livestock. Its digestively $(65 \%)$ is relatively high, and its protein content (1.9-5.2) low but nevertheless voluble (NRC, 1996). In Ethiopia, teff straw is the preferred binding material for wall, bricks, and house hold containers made of clay. As the same time Ethiopian farmers, prefer to grow teff because of its adoptability to different environment and soil conditions resistance to water stress, disease, and insect pests.

\section{POTENTIAL OF IMPROVED TECHNOLOGIES AND TEFF YIELDS}

Despite the importance of teff in Ethiopia, yields are remarkably low. While in 2012 - 2013, teff land productivity reached 1.4 ton per hectare, this is rather low when compared to other cereals such as maize ( 3.1 ton per hectare), rice (2.8 ton per hectare) and wheat (2.1 ton per hectare) (CSA 2013). Several factors explain this 
low yield. First, modern input use in teff production such as inorganic fertilizer and improved seed is low. Latest national estimates show that only two percent of teff farmers used improved seeds, although more than one third applied fertilizer for teff production (CSA 2012). Second, plant lodging, to which teff is susceptible, is perceived to be detrimental for teff grain production, especially during the grain-filling period (Berhe etal., 2011). Third, land is repeatedly ploughed before sowing to prepare the seedbed and control weeds, but this leads to increased erosion and lower soil fertility (Tulema etal., 2008; Fufa etal., 2011). Fourth, soil erosion has led to nutrient (mainly nitrogen and phosphorus) deficiencies in the drier areas of the country (Habtegebrial etal., 2007). Finally, there are significant post-harvest and processing losses (Fufa etal., 2011).

Overall, research on improved teff technologies has received limited international attention mainly because of the crop having only local importance (Berhane etal., 2011; Fufa etal., 2011). Not only has international funding for teff research been low, but national research also has been limited with institutions carrying out research on teff being understaffed. The crop therefore suffers from a lack of in-depth knowledge, which complicates extension efforts aimed at increasing teff production (ATA, 2013b). However, some improved technologies have been identified to stimulate teff productivity. Experiments on genetic improvements and breeding achieved substantially higher teff grain yield (a 34 percent increase) in research settings. However, the improved teff varieties have not been widely accepted, seemingly associated with low consumer demand for the better performing varieties (Teklu and Tefera 2005; ATA 2013b). Later studies showed the potential of better land management for enhanced teff production reduced tillage (Tulema etal., 2008), nitrogen fertilization (Habtegebrial etal., 2007), and water conservation measures (Araya etal., 2012) but only in research settings.

It has been argued recently that low teff productivity is partly caused by the way farmers sow teff seed.

\subsection{Effects of method of sowing and seed rate on teff yield \\ 3.1.1 High seed rate (broadcast)}

Traditionally, farmers broadcast the seed using a rate of $25-50 \mathrm{~kg}$ per hectare (ATA 2013c). This practice reduces yields because of the uneven distribution of the seeds, higher competition between plants for inputs (water, light and nutrients), and difficult weeding once the plants have matured (Fufa etal., 2011). For broadcast sowing, very poor establishment percentages are common, often falling below 50 percent (Oyewole etal., 2010). Part of this is due to rough seedbeds, poor seed covering and poor contact between seed and moist soil. Additionally, where seed is hand harvested and stored on-farms, quality can be poor because of storage at high temperature and moisture. Sticks, stones and weed seeds reduce quality further. With such poor seed, farmers have to use very high seed rates to obtain adequate plant populations. The optimum seed rate for broadcast crops can be twice that for drill-sown crops. Maximum yield in broadcast crops is also likely to be lower. This in part is because applied fertilizer is mixed through the soil rather than placed near the seed as in drilling, so is less directly accessible to plant roots.

For germination to occur in seeds there is the need for row seeded to be in perfect contact with the soil to facilitate water uptake (Oyewole etal., 2010). Broadcasting does not bring seed in perfect contact with the soil for water uptake (Oyewole etal., 2010), which must have accounted for the observed reduction in mean stand count among broadcast plots in comparison with the broadcast. The broadcasting system with poor quality of seed, poor soil fertility, and seed rate which is $25-50 \mathrm{~kg} / \mathrm{ha}$ which make the mature plant to lodge i.e. fall over. All these things affected the production of teff (Tareke, 2008). A research was conducted at Debrezeit Agriculture research center by using $25 \mathrm{~kg} / \mathrm{ha}$ but the result was very low as comparing to row sowing. The yield of the broadcasting plot was $500-1200 \mathrm{~kg} / \mathrm{ha}$ on the other hand the transplanted ones have given 3,400$5,100 \mathrm{~kg} / \mathrm{ha}$. This shows the new row planting has a four-fold increase in yield.

One of the risks associated with higher plant populations is the increased potential for lodging which can impact yield and quality. This may be particularly true under high yield environments like the Red River Valley. When using higher seeding rates, growers are advised to select semi-dwarf and shorter-straw varieties or varieties with very strong straw strength. Another consideration of higher plant stands is a thicker canopy which may lead to higher disease pressure. Scouting will be important during the season to monitor disease pressure in case fungicide applications are warranted. As a solution, it has been proposed to reduce seed rates and to plant seed in rows or to transplant seedlings (as is often done for rice, for example).

\subsubsection{Low seed rate (row) planting}

Reducing the seed rate to between 2.5 and $3 \mathrm{~kg}$ per hectare allows for reduced competition between seedlings and optimal tillering of the teff plants. By row planting or transplanting the seeds, land management and especially weeding can also be done more readily and the incidence of lodging is reduced (Berhe etal., 2011; Chanyalew and Assefa, 2013).

As applied in conventional horizontal farming or gardening is a system of growing crops in linear pattern in at least one direction rather than planting without any distinct arrangement. It is practiced in most crops whether direct seeded, transplanted or grown from vegetative planting materials, both in monocropping and multiple cropping (Ben Bareja, 2011). 
Crops are planted in rows or straight lines, either singly or in multiple rows, mainly to enhance maximum yields as well as for convenience (Ben Bareja, 2011).

The specific advantages of row planting over broadcasting or scatter planting include the following: (1) light absorption is maximized and, conversely, the excessive shading effect of other plants is minimized thus favoring more efficient photosynthesis and improved crop yield; (2) wind passage along the interrows is enhanced which increases gas exchanges and prevents excessive humidity; (3) access through the interrows facilitates cultivation, weeding, and other farm operations including hauling; (4) movement within the crop area is convenient and allows close inspection of individual plants; and (5) visibility is enhanced.

A four-row seeder has been developed in Ethiopia with a new type of seed metering mechanism uses labour efficiently and effectively. Field tests have shown that the row seeder can work net additional crop management intervention proposed to facilitate the control of grass weeds in peasants' teff fields in Ethiopia is row sowing (vs. the traditional practice of broadcasting seed and fertilizer): weeds emerging in the inter-row space could be more readily controlled either by hand pulling or by using a mechanical weeded than broadcast sowing. The limitation to row sowing teff by hand in Ethiopia is the high labour and time requirement (Melese etal., 1996).

The row seeding (vs. broadcasting) had a significant effect on heading, plant height, spike density tillering/plant, biomass yield, grain yield and harvest index. Row seeding in contrast to broadcasting increased teff plant height ( 91.9 vs. $89.0 \mathrm{~cm}$ ), the number of teff spikes $\mathrm{m}^{2}$ at maturity (507 vs. 438$)$, the number of days to heading for the crop (66.9 vs. 66.1), and teff biomass yield (9271 vs. $8480 \mathrm{~kg} / \mathrm{ha})$; resulting in the relatively uniform teff grain yield across treatments (i.e., $3188 \mathrm{~kg} /$ ha for row seeder vs. $3082 \mathrm{~kg} /$ ha for broadcasting.

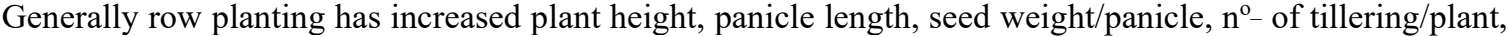
straw yield, grain yield and harvest index over broadcast method of sowing.
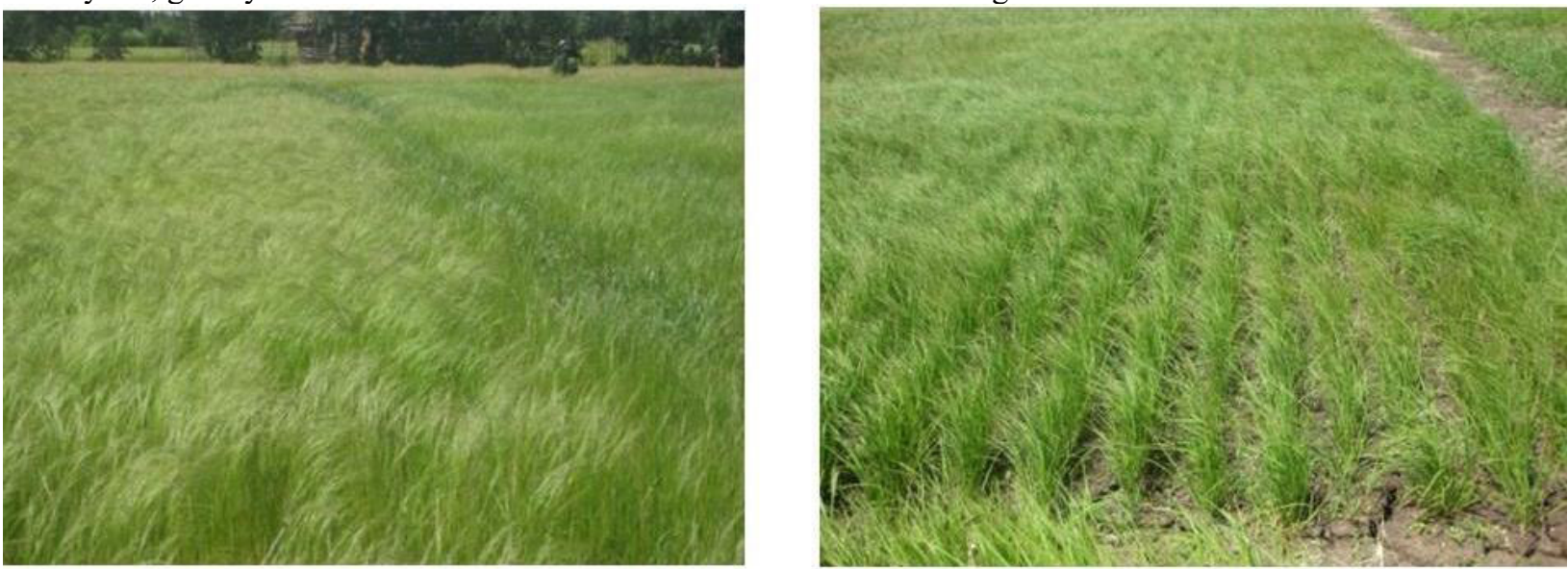

Figure 2 Teff sowing practice using traditional broadcasting (left) versus row planting (right)

$[\mathrm{P}$
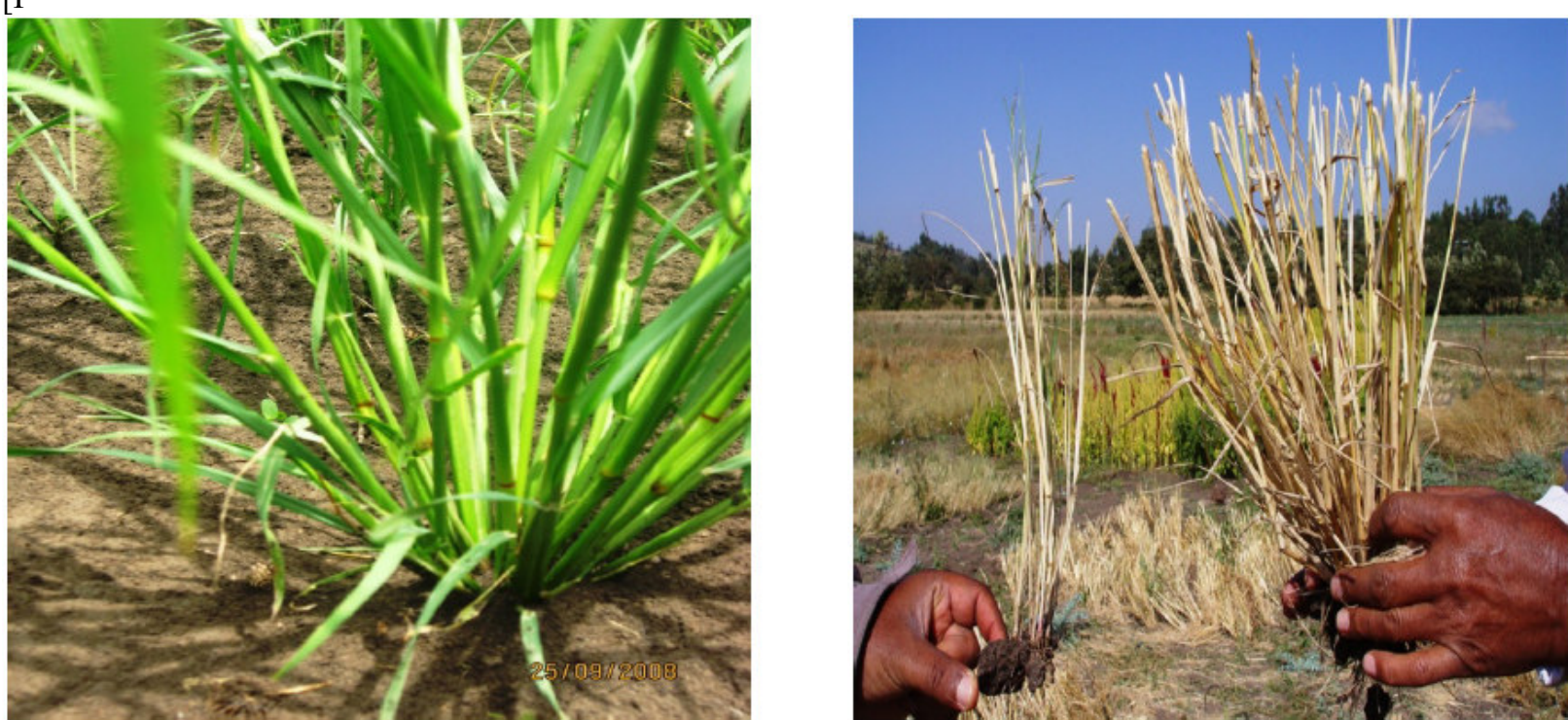

Figure 3 Photos showing tillering potential of transplanted teff 


\subsection{Some of data illustrating results}

\subsubsection{Yield increases under new technologies}

Row planting and transplanting technologies produced especially high yields, on average increasing yields by $70 \%$ from the national average of 12.6 quintals/ha to 20.9 quintals/ha. In Amhara and Oromia transplanting produced the highest yields followed by row planting and broadcasting. Transplanting in these two regions produced the highest regionally averaged yields of any technology with 23 quintals/ha. In SNNP and Tigray row planting produced the highest average yields of 22 and 21 quintals/ha respectively. Transplanting in SNNP and Tigray produced the second highest average yield, with broadcasting producing the lowest in comparison to the other two technologies. Across all regions broadcasting showed the lowest yields, though with the exception of SNNP broadcasting still achieved significantly improved yields over the national average. In Tigray for instance broadcasting yields were 17 quintals/ha, a 30\% increase over the national average. As planting method was only one component of the tef technology package, this increase in yield from broadcasting compared to the national average can be attributed to the other components of the package (ie quncho seed, reduced seed rate, etc.).

\section{Average yield by planting method Quintals/hectare}
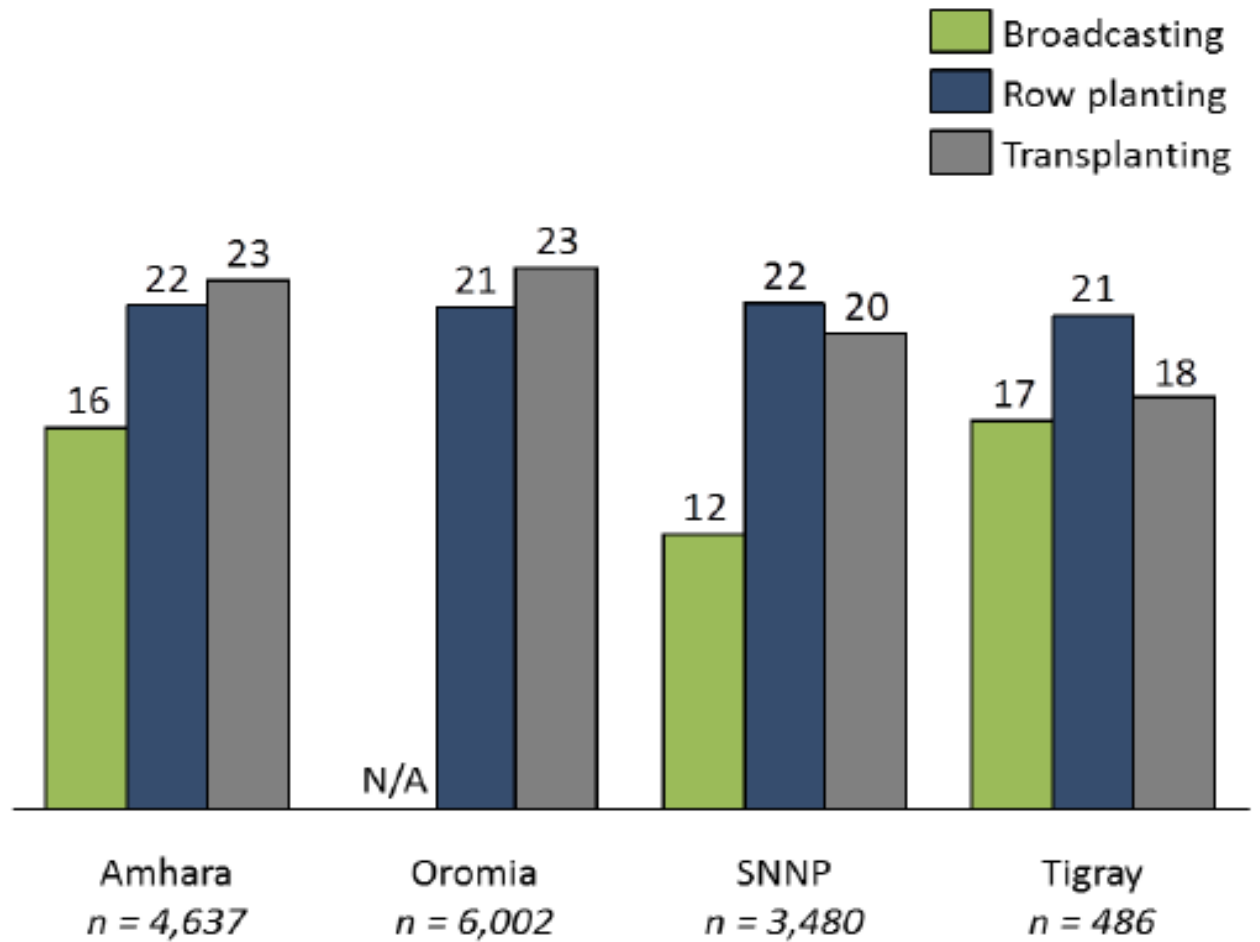

Figure 4: Average yield by planting method across all four targeted regions.

In these top performing areas average yields were between 31 and 36 quintals/ha, an over $250 \%$ increase from the national average. Variance in these top performing areas was also high with maximum yields ranging from 20 to $200 \%$ more than the areas' average.

Across all regions average validated farmer yields were higher than average FTC yields. FTCs practiced four types of planting methods. Transplanting with fertilizer and quncho seed consistently had the highest yields. Amhara, Oromia, SNNP and Tigray reported average FTC yields from transplanting at 18.0, 20.1, 22.7 and 18.9 quintals/ha respectively. Average validating farmer yields practicing various types planting methods in the same regions were 20.47, 21.26, 20.72 and 20.55 quintals/ha respectively. Only in SNNP did the FTC's highest yielding planting method outperform the region's average validated farmers. 


\section{Average yields by experimental plot across regions}

\section{Quintal/hectare}

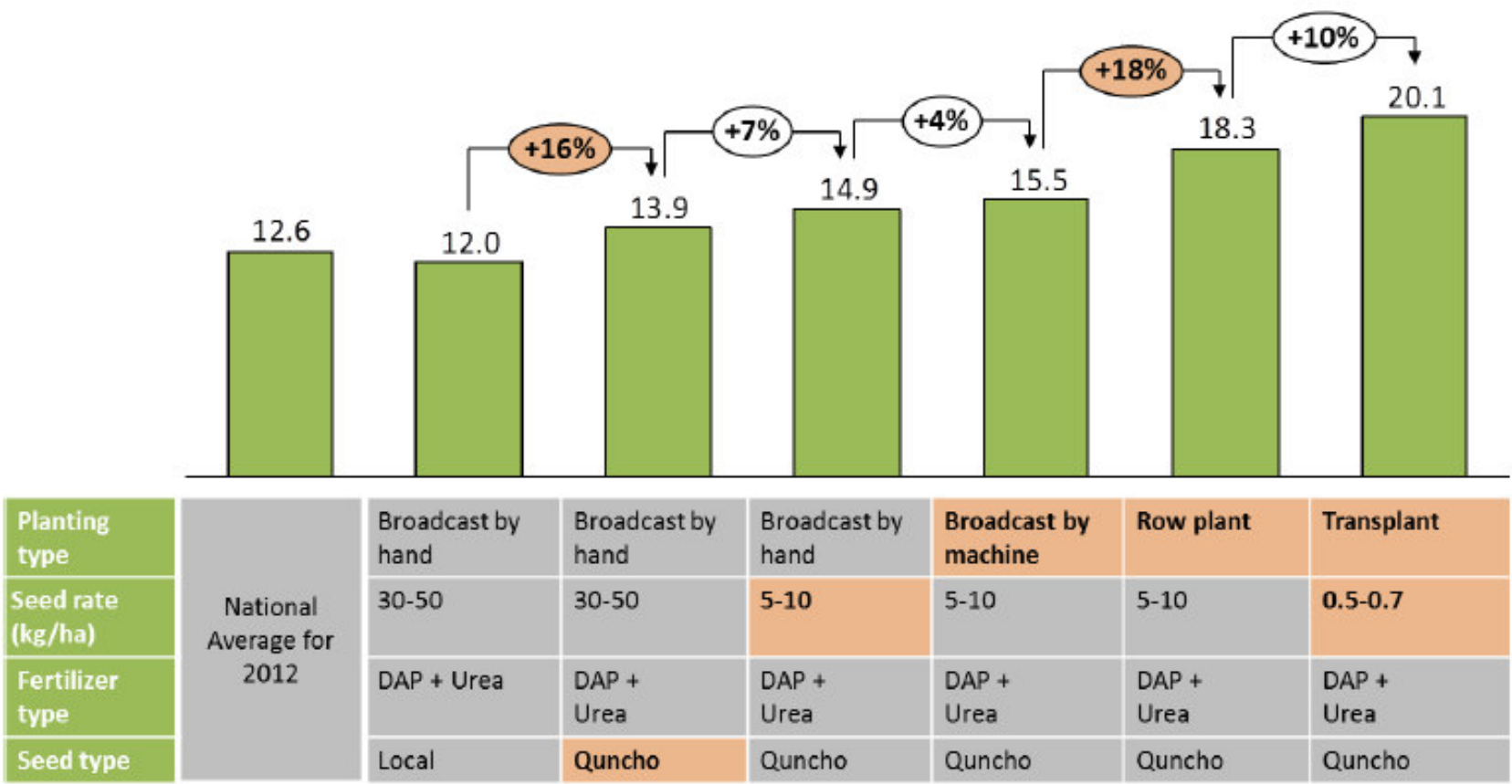

Figure 5: Average yield from FTCs experimental plots testing various components of the 2012 teff technologies.

\subsubsection{Drivers of Yield Improvements}

FTC's monitored the specific yield impacts of fertilizer use, improved seed use, reduced seed rate and planting method (Figure 4). The biggest yield increases came from adoption of quncho seed and switching from broadcasting to row planting, which showed $16 \%$ and $18 \%$ yield increases respectively. The smallest increase was the adoption of broadcasting at reduced seed rate which produced a $4 \%$ yield increase. Overall, in comparison to the national average, using transplanting with a reduced seed rate, fertilizer and quncho seed, FTC's observed a $60 \%$ yield increase.

Not all interventions had consistent yield results. The adoption of transplanting as a planting method had the highest standard deviation at $11.4 \mathrm{~kg} / \mathrm{ha}$. This was followed by row planting, where FTC's reported results varied with a standard deviation of $9.4 \mathrm{~kg} / \mathrm{ha}$. The most consistent yield results came from the traditional method of broadcasting with $30-50 \mathrm{~kg} /$ ha seeding rate and no fertilizer or improved seed. While the standard deviation for this method was $6.9 \mathrm{~kg} / \mathrm{ha}$, the average yield was below the national average at 8.4 quintals $/$ ha.

All regions reported FTCs having highest yields from transplanting with fertilizer and quncho seed, however, the percentage yield increase was different. Amhara, Oromia and SNNP had relative yield increases from hand broadcasting without fertilizer and local seed varieties to transplanting with fertilizer and quncho seed of $124 \%, 148 \%$ and $177 \%$ respectively, while Tigray FTCs recorded just $60 \%$.

In all regions the largest yield increases from FTCs came from the use of quncho, fertilizer, reduced seed rates and machine broadcasting, followed by the transitioning to row planting from machine broadcasting.

\subsubsection{Seeding Rate \& Variety:}

Validating farmers seeding rate ranged from $4 \mathrm{~kg} / \mathrm{ha}$ to $11 \mathrm{~kg} / \mathrm{ha}$, a significant decrease from the national average of $30 \mathrm{~kg}-50 \mathrm{~kg} / \mathrm{ha}$. Seed rating varied by planting method, where farmers using broadcasting used on average $11 \mathrm{~kg} / \mathrm{ha}$, row planting farmers used $10 \mathrm{~kg} / \mathrm{ha}$ and transplanting used significantly less at just $4 \mathrm{~kg} / \mathrm{ha}$ (Figure 5). Including national data, an inverse relation between seed rating and average yield can be observed. While nationally $30 \mathrm{~kg}-50 \mathrm{~kg} / \mathrm{ha}$ typically yields 12.6 quintals/ha, transplanting had an average yield of 22 quintals/ha with a $4 \mathrm{~kg} / \mathrm{ha}$ seeding rate.

While the increases in yields are likely mostly the result of the improved agronomic practices, these results show reduced seed rates could also have an effect on the higher yields. The comparison between the national average and the reduced seed rate broadcasting shows a two quintal per hectare yield increase by reducing the seed rate from 30 to 11 quintals per hectare.

Quncho was by the far the most commonly used seed variety by validating farmers, with $95 \%$ of validating farmers using the improved seed. 


\section{Average seed rate and yields by planting type across regions}

\section{Yield (quintal/hectare), Seed rate ( $\mathrm{kg} /$ hectare)}

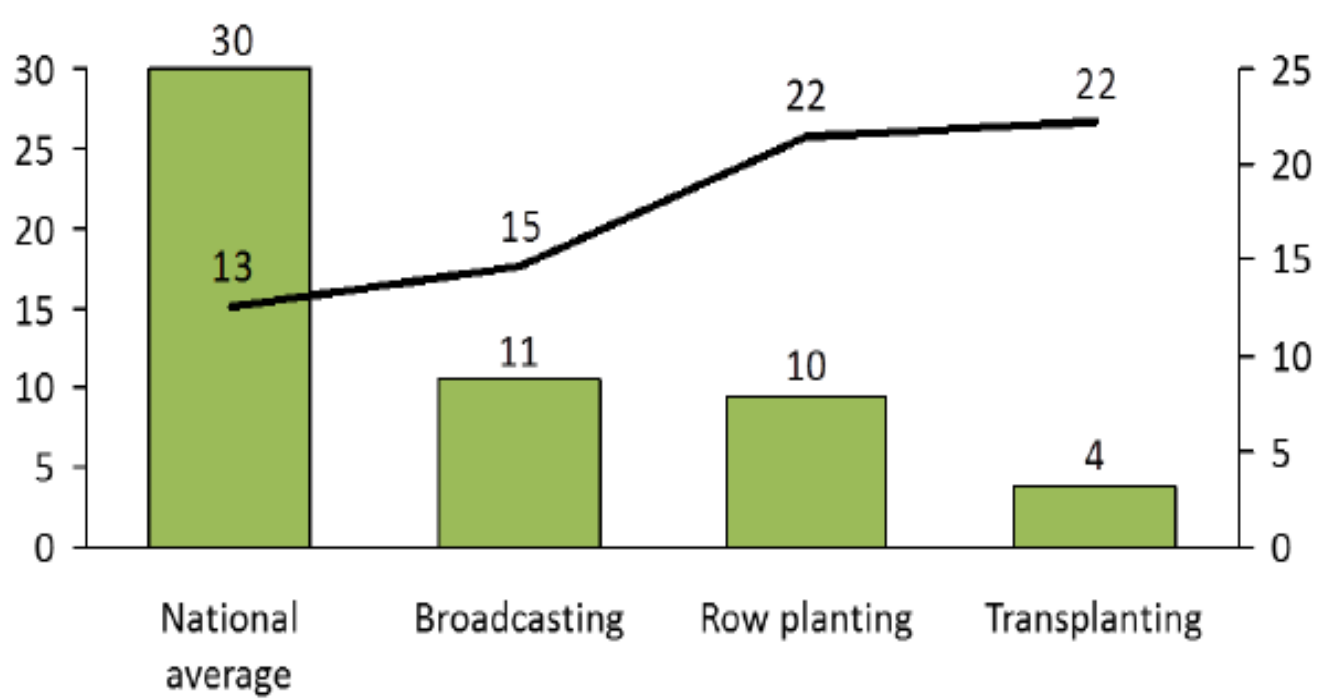

Figure 6: Average seed rate and yields by planting type by validated farmers compared to the national average as reported by CSA.

\subsubsection{Fertilizer Application}

Consistently across all four regions DAP application recommendations were matched while urea application fell short. DAP application rates varied from $99 \mathrm{~kg} / \mathrm{ha}$ in Amhara and Tigray to $100 \mathrm{~kg} / \mathrm{ha}$ in SNNP with relatively small standard deviations in comparison to urea. Tigray experienced the highest standard deviation of $6.5 \mathrm{~kg} / \mathrm{ha}$ in DAP application, however, still that was more consistent than urea standard deviations. Urea application ranged from the lowest average regional application of $86 \mathrm{~kg} / \mathrm{ha}$ in SNNP to the highest of $91 \mathrm{~kg} / \mathrm{ha}$ in Tigray. Urea application rates were also highly variable with a standard deviation across the four regions of $24.6 \mathrm{~kg} / \mathrm{ha}$. Tigray came closest to meeting urea recommendations, though was most inconsistent in meeting DAP recommendations.

No strong trend appears between planting method and fertilizer application. Regardless of broadcasting, row planting or transplanting, validated farmers applied similar amounts of fertilizer.

\subsubsection{Planting Time}

Yield increases averaged across all technologies varied in relation to week planted intervals from as high as $89 \%$ increases to $61 \%$ increases. While data on farmers who planted outside of the traditional planting period (third week of July to the first week of August) is limited, nationally averaged validated farmers who planted earlier experienced higher yields (Figure 6). This averaged national result can be misleading on it's as rainfall patterns are regionally specific and thus ideal planting times vary depending on farm location. Around $60 \%$ of the validated farmers planted between the third week of July and the first week of August. Planting at this time, farmers experienced average yield increases between $62 \%$ and $72 \%$ against the national average. Farmers planting earlier, from the third week in June to the second week in July experienced average yield increases between $66 \%$ and $89 \%$. This dramatic increase, specifically in the third week of June, where farmers planting then experienced $89 \%$ average yield increases could largely be driven by transplanting and also by giving the teff plant a longer growth period when moisture was sufficiently available.

The yield effects of early planting should be caveated with the relatively small sample size. Less than $10 \%$ of the validated farmers planted before the traditional planting period, and some of the yield increases are likely affected by transplanting. Furthermore planting times are geographically specific, depending on rainfall patterns and thus data collected across a wide geographic area may be misleading. 
Average productivity increase by planting time

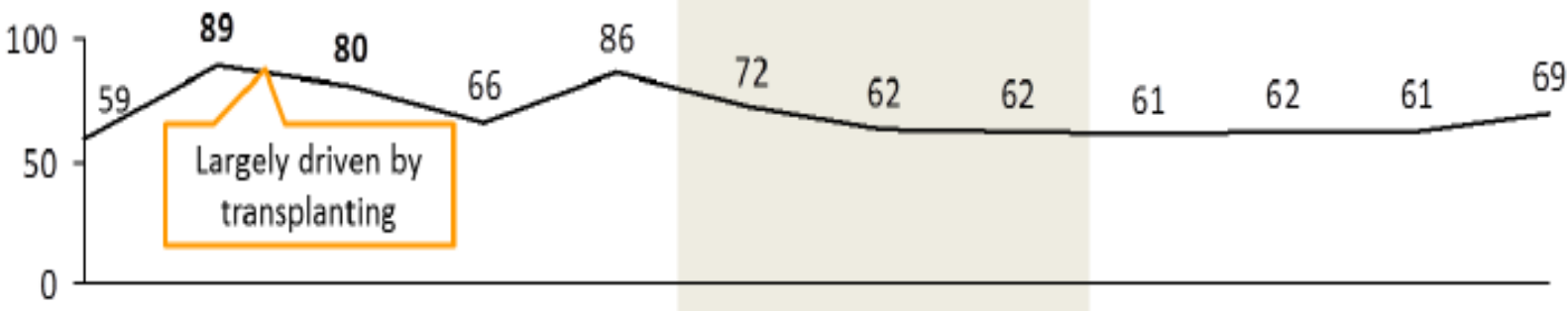

June June June July July July July August August August August Sept

Week 2 Week 3 Week 4 Week 1 Week 2 Week 3 Week 4 Week 1 Week 2 Week 3 Week 4 Week 1
$0.1 \%$
$0.3 \%$
$0.8 \%$
$2 \%$
$5 \%$
$16 \%$
$24 \%$
$19 \%$
$7 \%$
$4 \%$
$4 \%$
$1 \%$

Figure 7: Average productivity across all regions by planting time

\section{CONSTRAINTS OF TEFF ROW PLANTING}

Even though ATA research tends to find large positive effects to row planting (even if it is scaled up), these alternative agronomic research findings cast some doubts on the claim that row planting is able to achieve enormous yield increases. Overall, but there are doubts on the universal positive effect of row planting.

Manual row seeding is extremely labor intensive and unacceptable to peasant farmers in Ethiopia (Assefa etal., 1997). Row seeders developed elsewhere have not been accepted in Ethiopia because they were either too labor inefficient or ineffective in cloddy and rough fields.

According to ATA data's and perceptions gathered from farmers and FTCs from potential teff growing regions, some of the challenges encountered to teff row planting were:

\subsection{Row Planting:}

- Too much moisture hindered mechanized row planters and BBM implements

- In heavy rains collapsed rows caused mixing of fertilizer and seeds

- Fertilizer was often broadcasted while seeds were planted in rows

\subsection{Transplanting:}

- Delayed nursery establishment

- Moisture stress weakened seedlings

- Seedlings were raised in poor soils with higher seed rates prolonging the seedling preparation process

- Insufficient number of seedlings resulted in partial planting of plots

- Grass hoppers and mole cricket pests destroyed seedlings in some locations

- Seedling preparation was not in synch with teff planting times

- Seedlings were not transplanted at the appropriate growth stage

- Seedlings were planted with incorrect spacing

- Seedlings were planted in overly compacted fields

- Pest attacks on transplanting plots

\section{SUMMERY}

Agriculture is the basis of Ethiopian economy, accounting for $46 \%$ of its GDP and $90 \%$ of its export earning and employing $85 \%$ of the countries labor force. Increasing agricultural productivity is absolutely necessary to feed the increasing population by increasing land productivity.

Teff is Ethiopia's most important staple crop. Teff has the largest value in terms of both production and consumption in Ethiopia and the value of the commercial surplus of teff is second only to coffee. However, despite its importance in Ethiopia, teff yields are low. There are several reasons for this; one of the major reasons is the way farmers are sowing teff. The others are limited knowledge about possible avenues for improving teff productivity, combined with problems inherent to teff botany, limited national and international attention on Teff research, its localized importance in Ethiopia, agronomic constraints that include, lodging, low modern input use, and high post-harvest losses.

Technologies such as row planting and transplanting, where the seed rate is reduced and more space 
between seedlings is given, are assumed to be superior to traditional broadcasting because they allow for weeding, diminish competition between teff seedlings, allow for better branching out (tillering) of teff plants and to give high yield.

Even though ATA research tends to find large positive effects to row planting alternative agronomic research findings cast some doubts on the claim that row planting is able to achieve enormous yield increases.

\section{References}

Araya, T., W. M. Cornelis, J. Nyssen, B. Govaerts, D. Raes, K. D. Saire, and J. Deckers. 2011. "Building Resilience Against Drought and Soil Erosion : Impact of Field Water Conservation in the Drought Prone Vertisol Areas of Northern Ethiopia." In Online Conference Proceedings of the 8th International Symposium Agro Environ.

Assefa, K., S. Aliye, G. Belay, G. Metaferia, H. Tefera, and M. E. Sorrells. 2011. "Quncho: The First Popular Tef Variety in Ethiopia.” International Journal of Agricultural Sustainability 9 (1).

Assefa, K., S. Aliye, G. Belay, G. Metaferia, H. Tefera, and M. E. Sorrells. 2011. "Quncho: The First Popular Tef Variety in Ethiopia." International Journal of Agricultural Sustainability 9 (1).

ATA (Agricultural Transformation Agency). 2013b. “Working Strategy for Strengthening Ethiopian's Tef Value Chain Vision, Systemic Challenges, and Prioritized Interventions". Addis Ababa, Ethiopia.

Berhane, G., Z. Paulos, and K. Tafere. 2011. "Foodgrain Consumption and Calorie Intake Patterns in Ethiopia." ESSP II Working Paper 23. International Food Policy Research Institute (IFPRI). Addis Ababa, Ethiopia.

Berhe, T., Z. Gebretsadik, S. Edwards, and H. Araya. 2011. "Boosting Tef Productivity Using Improved Agronomic Practices and Appropriate Fertilizer." In Achievements and Prospects of Tef Improvement. Proceedings of the Second International Workshop, November 7-9, 2011, Debre Zeit, Ethiopia, edited by K. Assefa, T. Solomon, and Z. Chanyalew.

Costanza, S., DeWet, J. and Harlan, J. 1979. Literature review and taxonomy of Eragrostis tef (tef). Econ. Bot., 33.

CSA (Central Statistical Agency). 2012. “Agricultural Statistics Abstract: Agriculture”. Addis Ababa, Ethiopia.

CSA (Central Statistical Agency). 2013. "Agricultural Sample Survey: Area and Production of Major Crops, Meher Season". Vol. I. Addis Ababa, Ethiopia.

Dadi, L., M. Burton, and A. Ozanne. 2004. "Duration Analysis of Technological Adoption in Ethiopian Agriculture." Journal of Agricultural Economics 55 (3).

Dorosh, P., and S. Rashid. 2013. "Food and Agriculture in Ethiopia: Progress and Policy Challenges". University of Pennsylvania Press. Philadelphia, USA.

Endeshaw, B. 1989. Lysine and other essential amino acids in various fractions of major tef seed proteins. In: Cereals of the semi arid tropics. IFS, Cameroon.

Etagegnehu, G. 1994. A comparative study of the leaf ultrastructure of wheat (Triticum aestivum L.) (C3), maize (Zea mays) (C4) and tef (Eragrostis tef (Zucc.) Trotter). M.Sc thesis. Wye college, University of London, UK.

Fufa Hundera, Tesfa Bogale, Hailu Tefera, Kebebew Assefa, Tiruneh Kefyalew, Abera Debelo and Seyfu Ketema, 2001. Agronomy research in tef. In: Hailu Tefera, Getachew Belay and Mark Sorrels (eds.). Narrowing the rift. Tef Research and Development. Proceeding of the nternational Workshop on Tef genetics and Improvement, Debre Zeit, Ethiopia, 16-19 October 2000.

Fufa, B., B. Behute, R. Simons, and T. Berhe. 2011. "Tef Diagnostic Report: Strengthening the Tef Value Chain in Ethiopia". Addis Ababa, Ethiopia.

Germer, Renate (1985). Flora des pharaonischen Ägypten. Mainz: von Zabern. ISBN 3-8053-0620-2.

Habtegebrial, K., B. R. Singh, and M. Haile. 2007. "Impact of Tillage and Nitrogen Fertilization on Yield, Nitrogen Use Efficiency of Tef (Eragrostis Tef (Zucc.) Trotter) and Soil Properties." Soil and Tillage Research 94 (1)

Haftamu Gebretsadik1, Mitiku Haile2 and *Charles F. Yamoah2 (2009). Tillage Frequency, Soil Compaction and N-Fertilizer Rate Effects on Yield of Teff (Eragrostis Tef (Zucc) Trotter) in Central Zone of Tigray, Northern Ethiopia. Volume 1 (1):

Hailu, T., Seyfu, K. and Tesfaye T. 1990. Variability, heritability and genetic advance in tef (Ergarostis tef (Zucc.) Trotter) cultivars. Tropical Agriculture 67.

Hirut, K., Johnson, R. and Ferris, 1989. Physiological responses of Eragrostis tef to temperature. Physiologia Plantarum 77.

Ingram AL, Doyle JJ (2003). "The origin and evolution of Eragrostis tef (Poaceae) and related polyploids: Evidence from nuclear waxy and plastid rps16". American Journal of Botany 90 (1). doi:10.3732/ajb.90.1.116.

Minten, B., S. Tamru, E. Engida, and T. Kuma. 2013. Ethiopia's Value Chains on the Move : The Case of Teff. ESSP II Working Paper 52. International Food Policy Research Institute (IFPRI). Addis Ababa, Ethiopia. 
Mulatu Demeke (1999). Agricultural technology, economic viability, and poverty alleviation in

Murphy, Denis J. People, Plants, and Genes: The Story of Crops and Humanity. Oxford: Oxford University Press, 2007.

Oyewole C. I., Ajayi. O. and Ojuekaiye. R O. (2010): evaluation of yields of seven upland rice (oryzae sativa) cultivars sown by three methods in anyigba, kogi state, Nigeria: African Journal of Agricultural Research Vol. 5(16), 18 August, 2010.

Phillips, S. 1995. Flora of Ethiopia and Eritrea, vol. 7. Poaceae (Gramineae). National erbarium, Addis Ababa University, Addis Ababa, Ethiopia and Department of Systematic Botany, Uppsala University, Uppsala, Sweden

Seyfu Ketema., 1997.Tef:[Eragrostis tef (Zucc.)Trotter]. Promoting the conservation and use of under utilized and neglected crops, 12.Institute of plant genetics and crop plant research, Gatersieben / International plant genetics resource institute, Rome Italy.

Tadesse, E. 1975. Tef (Eragrostis tef) cultivars. Morphological and classification. Part II. Agricultural Experimental Station Bulletien, 66, Addis Ababa University, College of agriculture, Dire Dawa, Ethiopia.

Tareke Berhe* and Nigusse Zena(2008). Results in a trial of system of teff intensification ( sti ) at debre zeit, Ethiopia.

Tavassoli, A. 1986. The cytology of Eragrostis with special reference to E. tef and its relatives.Ph.D. dissertation, London University, London, UK

Teklu, Y., and H. Tefera. 2005. "Genetic Improvement in Grain Yield Potential and Associated Agronomic Traits of Tef (Eragrostis Tef)." Euphytica 141 (3)

Tulema, B., J. Aune, F. Johnsen, and B. Vanlauwe. 2008. "The Prospects of Reduced Tillage in Tef (Eragrostis Tef Zucca) in Gare Arera, West Shawa Zone of Oromiya, Ethiopia.” Soil and Tillage Research 99 (1)

Turkestan. H. "The Netherlands Company Soil and Crop S\&C says it is wrongly accused of bio- piracy to patent Ethiopian grain Teff'.2008.http://www.tigraionline.com/sandc_responds.html. UNDP (2002). UNDP assistance in the fifth country program to the agricultural sector.

Vavilov, N. 1951. The origin, variation, Immunity and Breeding of cultivated plants. Ronald Press, New York. 